\title{
Rane 1970-e i filmski slučaj Tomislava Radića
}

\begin{abstract}
Gilić Nikica, Rane 1970-e i filmski slučaj Tomislava Radića (Early 1970s and the Cinematic Case of Tomislav Radić). „Poznańskie Studia Slawistyczne” 6. Poznań 2014. Publishing House Science and Innovate, pp. 91-104. ISBN 978-83-63795-51-1. ISSN 2084-3011.

Although his early feature length works - Živa istina and Timon - created quite a stir and could be called provocative at its time (the first half of 1970s), as much as they can be considered stylistically interesting with its focus on the documentary style, Tomislav Radic can hardly be called a typical dissident, regardless of the suggestion that the politics caused the hiatus in his filmmaking (found in Ivo Škrabalo's very influential history of Croatian cinema). He remained in the country after his initial experiences with the mainstream cinema institutions and even became a dean of the drama academy in Zagreb during socialism. Not surprisingly, after 1990 he was very close to the nationalist government and yet he became the author of the first artistically successful fiction film about the perils of (Croatian) transition - Što je Iva snimila 21. listopada 2003. The author is in this case more ambivalent than his work, but the fact that his films mix very freely facts and fiction (in all of his best works - from the 1970s as well as the 2000s and 2010s - actually encourage analytical merging of art and the man who made it, thus making the study of dissenting and contesting figures of socialism more challenging. The insight into aspects of Radić's work gives a very useful perspective on the complexities of working in the socialist context.
\end{abstract}

Keywords: Tomislav Radić; Živa istina; Timon; modernism; Pula Film Festival; documentary style

\section{Uvod}

Tomislav Radić, veoma zanimljiv hrvatski sineast s početka 1970-ih, pravu je filmsku karijeru nastavio tek nakon 2000, premda je i prije toga snimio nekoliko loših filmova, a bavio se i kulturnom politikom kao urednik na državnoj televiziji 1990-ih. To nije tako neobično - neki su umjetnički, politički i drugi subverzivni aktivisti iz socijalističkih zemalja nakon raspada istočnoga bloka ostvarili itekako uspješne karijere, a najpoznatiji 
su, dakako, oni iz politike ${ }^{1}$. No mnogi su se od njih u novom, postsocijalističkom svijetu pasivizirali, često ne svojom voljom (poput srpskog redatelja Slobodana Šijana) ${ }^{2}$ ili su još za vrijeme socijalizma iselili iz domovine, poput šahista Viktora Korčnoja i pisca Josifa Brodskog iz Sovjetskog saveza, političara Wolfganga Leonharda iz Istočne Njemačke te redatelja Miloša Formana i pisca Milana Kundere koji su napustili Čehoslovačku. Najpoznatiji je jugoslavenski emigrant vjerojatno bio političar Milovan Đilas, a u jugoslavenskom filmu najpoznatije su emigracije srpskih redatelja Dušana Makavejeva, koji je s manjim umjetničkim uspjehom nastavio raditi, te Lazara Stojanovića, koji je emigrirao nakon boravka u zatvoru ${ }^{3}$ (i, nažalost, napustio film), a može im se pridružiti i slučaj hrvatskog slikara, sineasta i konceptualnog umjetnika Vladimira Kristla koji je nastavio prilično uspješnu karijeru u SR Njemačkoj.

No sudbine oporbenjaka u socijalističkim zemljama nisu uvijek jednostavne - mnogi su činovi otpora (predstave, filmovi, knjige...) nastali bez posebne namjere da se provocira sistem ili postigne društvena promjena, jer se umjetnici veoma često vode umjetničkim, a ne političkim motivima, a ne treba podcijeniti ni neuhvatljivost privatnih motivacija i utjecaj slučaja. Stvaralačka sloboda jednostavno provocira vlasti i kad autori provokaciju ne postave kao svoj cilj. Također, mnogi su subverzivni autori s vremenom (ili odmah) izgubili kritičku oštricu u umjetničkom djelovanju pod svojim socijalističkim režimima. Bilo je dakle različitih situacija. Primjerice, hrvatski se redatelj Branko Marjanović nakon službene zabrane satire Ciguli Miguli iz 1952. godine posvetio dokumentarnim filmovima o životinjama, gdje nije postojala opasnost da opet politički zgriješi, dok se scenarist, pisac

1 Pisac Václav Havel, sindikalac Lech Wałęsa, politički aktivist Franjo Tuđman (predsjednici Češke, Poljske i Hrvatske), aktivisti Alija Izetbegović (predsjednik predsjedništva Bosne i Hercegovine) te Janez Janša (među ostalim, premijer Slovenije).

2 Šijan zastoj karijere nekih srbijanskih filmskih kontestatora socijalizma nakon raspada Jugoslavije objašnjava specifičnostima vlasti Slobodana Miloševića (cf. Oremović 2013: 39). Premda nije bio potpuno izbačen iz kinematografije, Šijan godinama nije mogao snimati cjelovečernje igrane filmove (u tom segmentu kinematografije, dakako, ideološka i politička kontrola uvijek su najčvršće).

${ }^{3}$ Razlog je Stojanovićevih problema bio radikalni Plastični isus, njegov diplomski rad. Isti je film Stojanovićeva mentora Aleksandra Petrovića (važnog srpskog redatelja i prije poznatog kao kontestatora) koštao posla na akademiji u Beogradu. 
i komunistički političar Joža Horvat (glavni krivac za subverzivnost toga filma) ipak povremeno vraćao u igrane filmske i televizijske projekte.

Dakle, pojedinačnim slučajevima valja prilaziti oprezno, a Tomislav Radić predstavlja upravo takav kompleksan slučaj, znakovit za društvene procese, no nesvodiv na velike povijesne sheme. Stoga je on vjerojatno izrazitije tipičan subjekt nego što su to politički velikani (Havel, Wałęsa) ili radikali-emigranti (Brodski, Makavejev, Kristl).

\section{Radićeva iznenađenja}

Ranih 1970-ih Tomislav Radić došao je na glas kao potencijalno sumnjiv i provokativan umjetnik, a povjesničar filma Ivo Škrabalo (Škrabalo 1998: 375) ističe da je hrvatski komunistički političar Stipe Šuvar, nakon političkih lomova 1971. godine zadužen za kulturu, kao predsjednik pulskoga žirija izravno zaslužan što Živa istina nije bila u službenoj konkurenciji toga festivala. Nakon drugog filma Timon Radić, prema Škrabalu (Škrabalo 1998: 384), ,puna dva desetljeća nije dobio priliku aktivno se baviti filmom", što u kodu jugoslavenske i hrvatske filmske publicistike jasno implicira da mu je politika te prilike uskratila. Sličan stav preuzima i kasniji Filmski leksikon (Karagić, Gilić (ur.) 2003)4, a Škrabalo ga ponavlja u još kasnijem, skraćenom izdanju svoje povijesti hrvatske kinematografije (Škrabalo 2008: 133).

No, s druge strane, Radić je ipak za vrijeme Jugoslavije s uspjehom i često radio i u kazalištu i na televiziji (premda je početkom 1970-ih propala jedna njegova politički potencijalno provokativna predstava u zagrebačkom kazalištu Gavella). Postao je i profesor (od 1978. do 1997. godine) ${ }^{5}$, pa čak i dekan (od 1982. do 1984. godine) na Akademiji za kazalište, film i televiziju u Zagrebu. Obično mu se pripisuju i zasluge za preimenovanje te

${ }^{4}$ Nakon Timona Radić ,,(u velikoj mjeri zbog političkih okolnosti) dugo ne uspijeva pronaći film. producente" (<http://enciklopedija.lzmk.hr/clanak.aspx?id=33197>, 28.05.2013). Članak nije potpisan, a u njemu se očito preuzima navedena Škrabalova implikacija da je Radićeva filmska karijera doživjela stanku zbog političke nepoćudnosti.

5 Prema članku o Radiću na stranicama festivala ZagrebDox (<http://zagrebdox.net/-hr/2012/program/retrospektive/autorska_vecer_tomislava_radica/popodne_serija_feljtona_ lica>, 20.02.2013). 
ustanove u Akademiju dramske umjetnosti, kako se ona i danas zove ${ }^{6}$, unatoč priličnoj upitnosti pojma „dramski”, koji bi očito trebao obuhvaćati sve izvedbene i filmske rodove. Dakako, Radićeva mogućnost rada u kazalištu, na fakultetu i na televiziji sama po sebi ne implicira da nije bilo političkih prepreka njegovom radu na filmu, jer je ideološka kontrola nad filmom često bila čvršća nego nad drugim navedenim djelatnostima, no ipak je teško smatrati pravim disidentom nekoga tko je ipak imao bogatu društvenu djelatnost, pa makar ona bila izvan filma.

Kod Radića, međutim, ni tu nije kraj iznenađenjima. Kada je 2005. godine ovaj veteran filma i kazališta predstavio javnosti cjelovečernji igrani film Što je Iva snimila 21. listopada 2003. godine, kritika je bila impresionirana. Damir Radić (2005), kritičar strog i prema političkoj orijentaciji Tomislava Radića, ali i prema njegovim prethodnim cjelovečernjim filmovima ( $L u k a$, Anđele moj dragi i Holding), o ovom filmu kaže:

Posve neovisno o moralnoj konstituciji svog autora, Što je Iva snimila 21. listopada 2003. izvanredno je, gotovo besprijekorno ostvarenje čvrste, a opet gipke i dinamične dramaturgije, sjajnih glumaca i redateljske realizacije, ultimativno autentičnog prikaza zbilje na svim razinama kojima se film bavi, a jedina zamjerka može se uputiti nedovoljnom isticanju glavnog fokalizatora, 15-godišnje Ive. Da se nešto više osvrnuo na dubinsku tugu te djevojčice, Radić je mogao ostvariti pravo malo remek-djelo (Radić 2005).

Na filmskom festivalu u Puli iste godine je film osvojio glavnu nagradu (za najbolji film), kao i nagradu za režiju te dvije glavne glumačke nagrade, a sličan je uspjeh nekoliko godina kasnije ponovila i Kotlovina, osvojivši nagradu za najbolji film, za scenarij, za zvuk, kao i tri od četiri glumačke nagrade. Oba su filma dobila i nagradu filmske kritike Oktavijan.

Dakle, premda je 1990-ih bio zagovornik dominantne hrvatske ideologije te autor blizak vlastima samostalne Hrvatske ${ }^{7}$, Radić je snimio film koji izrazito kritički govori o suvremenom hrvatskom društvu, o novom kapitalizmu i tzv. tranziciji - važnoj temi u umjetnosti svih postsocijalističkih

${ }^{6}$ Još su starija imena te ustanove: Akademija kazališne umjetnosti te Akademija kazališne i filmske umjetnosti (<http://snimanje.adu.hr/stivo/tekst04-2.html>, 20.06.2013).

${ }^{7}$ Bio je i urednik državne televizije, što je 1990-ih bila važna politička funkcija. Nije ju mogao obavljati netko tko nije veoma blizak vladajućoj stranci HDZ-u. 
društava $^{8}$. U području forme Radić se uklopio u trendove novih medija prikazavši cijeli film iz gledišta videokamere koju otac kupuje kćerki za rođendan i poigravajući se do kraja filma s idejom dokumentarizma kao postupka. No Radić je k tome prodro u izrazito kontroverzne i bitne teme suvremene Europe ${ }^{9}$. Nakon što je nekoliko prethodnih Radićevih filmova dobilo uglavnom loše ili, u najboljem slučaju, suzdržane kritike, navedenim je ostvarenjem započeo procvat karijere ovog autora rođenog 1940. godine.

Premda katkada hvaljen, dramski omnibus Tri priče o nespavanju (2008) u Puli nije osvojio niti jednu nagradu, no Kotlovina (2011) opet predstavlja potpun festivalski i umjetnički trijumf (cf. Pavičić 2011). Radić se ovim trima filmovima vratio svojim počecima, kada je bio jedan od najzanimljivijih filmskih redatelja, predstavnik estetičkih i političkih lomova, kao i sukoba oko autorskog filma i modernizma koji su obilježili 1960-e i rane 1970-e.

\section{3. Živa istina}

Prvo cjelovečernje igrano ostvarenje Tomislava Radića Živa istina spada među filmove koji krše sva pravila klasičnog djela namijenjenog kinodistribuciji, a može se smatrati jednim od najradikalnijih primjera autorskog filma u Hrvatskoj. To, dakako, ne znači da je riječ o ostvarenju bez prethodnika i srodnika: autori poput srpskih redatelja Želimira Žilnika i Dušana Makavejeva istraživali su granicu dokumentarnog i igranog filma te gledateljima nudili začuđujuće hibridne forme ${ }^{10}$, a srodnim se modelom služio i američki redatelj John Cassavetes. No u Hrvatskoj je taj pravac filmskog istraživanja ipak bio slabije razvijen nego, recimo, u Srbiji, pa Radićev doprinos time dobiva na težini. Živa istina $\mathrm{k}$ tome spada među radikalnije predstavnike umjetnički moćnog pseudodokumentarističkog modela filmske fikcije.

${ }^{8}$ Najkraće, dok otac obitelji pokušava sklopiti posao s poduzetnikom iz Europske unije (Nijemcem), ovoga zanima junakova supruga te ne smatra neprimjerenim tretirati je kao prostitutku.

${ }^{9}$ Posljedicama tranzicije bave se i Bure baruta Gorana Paskaljevića (u svijetu distribuiran kao Cabaret Balkan) te Ljilja 4ever Lukasa Moodysona.

${ }^{10}$ Vatroslav Mimica vjerojatno je najvažniji među hrvatskim igranofilmskim predstavnicima istraživanja filmske forme 1960 -ih, a svakako je i najradikalniji. 
Film je nastao u izrazito niskobudžetnoj produkciji, potpuno oslonjen na televiziju (baš kao i, početkom idućeg desetljeća, prvi cjelovečernji igrani film istaknutog hrvatskog redatelja Zorana Tadića ${ }^{11}$. Kako objašnjava sam Radić $^{12}$, svom je televizijskom producentu predložio da snimi materijale za film, pa ako od toga nešto bude, Televizija Zagreb (Heidl 2011b: 136) može dobiti film za veoma male novce, a ako projekt ne uspije, svakako će dobiti televizijsku emisiju, $\mathrm{k}$ tome snimljenu usput, uz druge televizijske zadatke, bez posebno velikih troškova. Snimatelj Drago Novak, tvrdi Radić, nije uopće ozbiljno shvatio redateljevu ambiciju da ovaj projekt ikada dođe u kinodvorane te je snimao kao što je i inače radio za televizijske emisije (Heidl 2011a). Radić ističe kako je ideja za film nastala nakon što je za tadašnju Televiziju Zagreb snimao reportaže (koje se mogu smatrati i dokumentarnim filmovima) o usamljenim ženama (Heidl 2011a; 2011b: 135). Na temelju tog iskustva Radić je zamislio film pod radnim nazivom Biografija, o glumici koja ne uspijeva naći uloge pa se bavi drugim poslovima - radi kao model ili kao manekenka. Stilski, projekt je zamišljen kroz tehnike tipične za dokumentarni film.

Potom je redatelj, kako sam ističe, u Zagrebu sreo svoju poznanicu, glumicu Božidarku Frajt, poznatu u javnosti, ali bez pravog glumačkog angažmana te se iz tog susreta i razgovora, ističe Radić, konkretizirala navedena općenita ideja filma o glumici. Razmišljati o igranom filmu namijenjenom kinima na temelju rada na televiziji tada nije bilo uobičajeno, ali ukoliko je televizijski producent bio naklonjen radu nekog autora, postojala je i ta mogućnost, pa Tomislav Radić sa zahvalnošću ističe producenta Televizije Zagreb $^{13}$ Angela Miladinova, bez kojeg bi Živa istina teško nastala (Heidl 2011a). Božidarka Frajt u Živoj istini glumi lik po mnogo čemu sličan njoj kao izvanfilmskoj osobi: glumica i njen lik dijele i ime i profesiju i trenutnu

11 I Tadić je u Ritmu zločina koristio svoje dokumentarističko i televizijsko iskustvo. Zanimljivo je da je nedugo nakon Radića i Rajko Grlić (predstavnik tzv. praške škole) započeo kino-karijeru filmom Kud puklo da puklo u kojem dokumentaristički stil snažno ulazi u igrani film. Dokumentarnim se filmom u svom igranom prvijencu izravno inspirirao i Petar Krelja (Godišnja doba). O ovom razdoblju hrvatskog filma vidi u Gilić 2011: 102-126.

12 Riječ je o svjedočanstvima nastalima u sklopu priprema filmskog kritičara i publicista Janka Heidla za monografiju o ovom autoru. Radićeva je svjedočenja Heidl (2011a) obradio i za internetski (nekoć tiskani) časopis ,Zapis”.

13 Ta se televizija u razdoblju nakon raspada Jugoslavije zove Hrvatska televizija. 
životnu situaciju (zastoj karijere), a upućeniji gledatelji prepoznaju i druge likove zasnovane na stvarnim osobinama njihovih interpreta.

Osobito je impresivna epizodna uloga Vjerana Zuppe, u to doba kazališnog intendanta, koji glumi kazališnog intendanta od kojeg junakinja filma očajnički traži posao ${ }^{14}$, a nastanak te scene Radić objašnjava ovako:

Vjeran Zuppa je bio moj tadašnji šef u kazalištu ITD u kojem je on bio ravnatelj, a ja šef tehnike. Učinilo mi se da bi bilo dobro napraviti jednu scenu u kojoj ta glumica, glavni lik filma traži posao, a ne može ga dobiti. Da se vidi kako to izgleda. Tako sam Zuppu, kojega sam, dakle, poznavao, kao stvarnog ravnatelja kazališta, pitao bi li on nastupio u mom filmu i na neki način odglumio, interpretirao, otjelovio ravnatelja kazališta koji odbija glumicu koja se u tom kazalištu želi zaposliti. Pristao je i to smo snimili u njegovom uredu. Ili u mom, ne sjećam se točno. Unaprijed određen tekst dijaloga nije postojao. Upute su bile da Boža traži posao, a da Zuppa, što god ona htjela, na to nikako ne pristaje. I tako su oni to izveli. Ja sam, kao i inače, stajao sa strane i Boži pantomimom, rukom i grimasama, davao upute: sad ga pogledaj, okreni se na drugu stranu, sad još inzistiraj, pitaj ga još nešto, sad šuti, sad sjedni, sad ustani... Kad sam tako prstom na svom licu pokazao da iz oka curi suza, ona se stvarno uspjela rasplakati, jer je uistinu sjajna glumica koja sve glumi pravo, kao da se stvarno događa i ima sposobnost da sve napravi i kaže kao da to radi prvi put (Heidl 2011a).

U maloj se ulozi u Živoj istini pojavljuje i redatelj Branko Ivanda koji glumi redatelja reklame, a njen je snimatelj Oktavijan Miletić koji se počeo baviti filmom još prije Drugog svjetskog rata ${ }^{15}$.

Premda je bio zadovoljan razradom koncepta, Radiću je nedostajao novac za završavanje Žive istine ${ }^{16}$, pa je nužno bilo obratiti se uobičajenim izvorima financiranja kino-filmova. Da bi se to ostvarilo, ističe Radić, Televizija Zagreb se službenim dokumentom morala odreći autorskih prava. Po tadašnjim pravilima televizijski film nije mogao dobiti novac predviđen

${ }^{14}$ Kritičar Polimac (2010) upozorava na moguću moralnu dvojbenost scene sa Zuppom: zbog miješanja fikcionalnog i dokumentarističkog gledatelj bi mogao steći dojam da se stvarni intendant Zuppa obračunava sa stvarnom glumicom.

15 „Scena snimanja reklame je čisti dokumentarac. Boža je stvarno snimala reklamu koju je režirao moj kolega Branko Ivanda. Pitao sam Branka možemo li doći s ekipom i to uključiti u film koji snimamo. On se složio i to je bilo sve. Snimatelj Brankove reklame bio je glasoviti Oktavijan Miletić pa se tako u mom prvom filmu slučajno našao i jedan od doajena hrvatske kinematografije" (Heidl 2011a).

${ }^{16}$ U ovom se dijelu, zbog nepostojanja drugih izvora, oslanjamo na Radićeva (Heidl 2011b) svjesni ograničenja takvog pristupa. 
za kino-filmove pa se televizija (opet zahvaljujući producentu Miladinovu) odrekla svih prava. No na natječaju za financiranje filmova projekt nije prošao, a televizija na njega više nije imala nikakva prava pa je projekt potpuno zamro. Međutim, Radićev film nastaje u osjetljivom vremenu političkog previranja. Kompletna je politička garnitura Hrvatske pročišćena zbog raširenosti „masovnog pokreta” (maspoka), danas često nazivanog „hrvatsko proljeće" ${ }^{\prime 17}$. Kao što ističe kritičar N. Polimac (2010), „Živa istina bila je veliki događaj u kinematografiji nad koju se već nadvila sjena Karađorđeva"18.

Radić tvrdi da su novi tvorci kulturne politike u Hrvatskoj bili zainteresirani za projekt koji nije bila odobrila prethodna, ,nacionalistička” garnitura, pa je film zato ipak dobio nužnu financijsku potporu. Pomalo iznenađujuće, pa i nasuprot dotadašnjim povijesnim sistematizacijama, Radić nam, govoreći u mikrofon kritičara Janka Heidla, otkriva da Žive istine možda ne bi bilo da nije smijenjeno hrvatsko rukovodstvo (Savka Dapčević-Kučar, Miko Tripalo i ostali političari). Nova, postproljećarska elita, pokazala je interes za film koji proljećarski funkcionari nisu financirali.

No to što je filmu odobreno prikazivanje u kinima, ne znači da je bio sasvim u skladu s dominantnim društvenim vrijednostima. Prije svega, važno je znati da je Festival igranog filma u Puli (središnji filmski događaj čitave Jugoslavije) u to vrijeme dobio selekciju jer je jugoslavenska proizvodnja filmova bila prilično velika, pa Živa istina tu selekciju nije prošla te, premda je smjela biti prikazana na festivalu, nije konkurirala za nagrade. Na stranu mogući politički razlozi, ipak su u Živoj istini upadljiviji neobični stilski postupci koji su mogli zbuniti žiri' ${ }^{19}$. Najvjerojatnije zbog toga što je imitirala dokumentarni film, a još k tome bila koncipirana kao modernistički dokumentarni film, grubih i nedovršenih montažnih spojeva, često nepreglednih prizora i situacija koje na prvi pogled gledatelju nisu sasvim jasne. Selekcijska se komisija vjerojatno pitala kakav je to uopće film. No

${ }_{17}$ Ovaj je naziv očita aluzija na nasilno ugušeno „praško proljeće” u ondašnjoj Čehoslovačkoj.

18 U Karađorđevu se Tito obračunao s buntovnim vodstvom hrvatskih komunista.

19 Žiri su činili (<www.pulafilmfestival.hr>, 27.06.2013): S. Šuvar, K. Cenevski, I. Milutinović, V. Shita, P. Šafer, K. Škanata, A. Tanović, I. Torkar i S. Zlatić. Na stranici je prezime I. Milutinovića napisano kao „Mulutinović”, no to je očita greška. Radić (Heidl 2011b) kaže da mu je K. Cenevski kasnije rekao da su film izbacili samo zato što nije u boji. Nemamo, dakako, čvrstih dokaza da je tako bilo, ali već sama ideja da bi se film mogao odbaciti na temelju obične stilističke odrednice prilično je znakovita za moguću opravdanost hipoteze da film nije odbijen zbog političkih, nego zbog formalnih razloga. 
Živa istina ipak je, izvan konkurencije prikazana u Puli, uz iznimno topao prijem jugoslavenskih kritičara i redatelja, koji su pokrenuli internu festivalsku, ali i medijsku kampanju u korist toga filma, a protiv žirija koji ga nije prepoznao.

Žiri pod predsjedanjem perspektivnog, a kasnije veoma uspješnog komunističkog političara i sociologa Stipe Šuvara ${ }^{20}$, popustio je pred pritiscima i dodijelio Živoj istini nagradu za najbolju glavnu žensku ulogu, premda film uopće nije bio u konkurenciji ${ }^{21}$. No ni tu nije kraj priče o neobičnoj sudbini ovog filma - kada je počeo igrati u kinima, pojavio se problem scene u kojoj junakinja s društvom gleda obiteljske filmove, u kojima se, među ostalim, pojavljuju i ustaše (kvislinška vojska marionetske Nezavisne Države Hrvatske u Drugom svjetskom ratu). Glas Arsena Dedića (već tada veoma poznatog pjevača i pjesnika) baš u toj sceni pjeva stihove o tome kako neke izgubljene bitke izgledaju kao pobjede ${ }^{22}$. Neke od tih stihova dobro je citirati:

\footnotetext{
Otkriva mi svoju tajnu i zločinac, starac sijed

Imao sam prošlost sjajnu, ganjao me čitav svijet

Počast se na kraju primi, ide vrijeme bije sat

Pobjedom se poslije čini izgubljeni neki rat.

Ove bitke, ove rane otkrit će ljepotu svu

Kada budu stvari davne, kad ne budu više tu.
}

Kako ističe sam Radić, udruga partizanskih boraca Drugog svjetskog rata SUBNOR (Savezno udruženje boraca Narodno-oslobodilačkog rata) osobito je u toj sceni vidjela potencijalno subverzivnu političku provokaciju, što ne čudi pretjerano s obzirom na važnost naracije o ratu za jugoslavensko društvo, pri čemu je SUBNOR predstavljao neku vrstu kolektivne jugoslavenske savjesti.

Međutim buka podignuta oko Žive istine nije bila dovoljna da zaustavi Radićevu karijeru. Nakon toga filma snimio je još jedan inovativan,

${ }^{20}$ Jedan od najglasnijih protivnika S. Miloševića u čitavom Savezu komunista Jugoslavije pri samom kraju te države bio je hrvatski član predsjedništva SFRJ.

${ }^{21}$ Iduće je godine pulski festival u svoj pravilnik unio odrednicu da se ne smiju nagrađivati filmovi koji nisu u konkurenciji za nagrade, što bi se valjda trebalo podrazumijevati.

${ }^{22}$ Kao što s pravom ističe Polimac (2010), i junakinja filma svjesna je kontroverznosti prikaza ustaša u naizgled sasvim običnom obiteljskom filmu. 
a zapanjujuće slabo primljen film. Timon, zanimljiv i samo po svojim filmskim osobinama, dio je multimedijskog umjetničkog koncepta. To je film o glumcu koji glumi Timona Atenjanina u Shakespearovom komadu, a u životu mu se događaju slične stvari kao i Timonu te pati od istog grijeha oholosti koji mu onemogućuje da ispravno sagleda ljude koji ga okružuju i predvidi što bi mu se moglo dogoditi ${ }^{23}$. Taj je film, međutim, nastao zajedno s kazališnom predstavom koju je Radić postavljao u zagrebačkom Hrvatskom narodnom kazalištu, a glumci iz te predstave glume likove koji u filmu odgovaraju njihovim kazališnim ulogama, pri čemu se Radićev postupak i u ovom filmu može smatrati uvelike dokumentarističkim. Izvrsna kamera Tomislava Pintera šesnaestmilimetarski format filma (očito je opet riječ o niskobudžetnom ostvarenju) koristi za postizanje intimnijeg filmskog prostora, u kojem spektakl kazališnog uspjeha i kompleksni junakovi odnosi s kolegama glumcima i ostatkom svijeta nikada ne izlaze iz okvira utjecaja na junakovu intimu.

Nadovezujući se na Živu istinu, u kojoj glumci, redatelji i intendanti glume glumce, redatelje i intendante, u filmu Timon glumci koji su radili s Radićem predstavu Timon Atenjanin glume glumce. Ti filmski glumci nastupaju, naravno, u predstavi Timon Atenjanin, u ulogama u kojima su se isti glumački likovi pojavljivali u stvarnoj kazališnoj predstavi, a likovi iz filma $\mathrm{k}$ tome nose ista imena koja nose isti glumci u stvarnom životu. Dakle, uz to što se razigrao u izrazito dokumentarističkom modelu stila filmske fikcije, u skladu s nekim subverzivnim filmskim tendencijama u socijalističkoj Jugoslaviji (Dušan Makavejev, Želimir Žilnik) i drugdje (dobar je primjer film poljskog klasika Andrzeja Wajde Čovjek od željeza), Radić je povezao i filmsku umjetnost s kazalištem (cf. Tretinjak 2012). U tome se pak Timon, a donekle i Živa istina, mogu uspoređivati i s remek-djelom Jacquesa Rivettea Pariz nam pripada te nekim filmovima Alaina Resnaisa.

Tolika formalna razigranost vjerojatno je pridonijela odbacivanju Radićevog koncepta od službene kinematografije (premda je pulski žiri bio popustio kod Žive istine), no sasvim se očitim čini da nije tek sadržaj filmova (prikazivanje ustaša u Živoj istini) otežao mogućnost da Radić snimi još neki igrani film. Opći je duh Žive istine i Timona izražajno pesimističan: baveći se umjetnicima u suvremenom urbaniziranom svijetu (očito

${ }^{23}$ U Škrabalovim je knjigama (1998 i 2008) Timonu posvećeno malo pažnje. 
u Zagrebu), Živa istina i Timon prikazuju njihovu egzistenciju izrazito mračno. Doduše, ne prikazuju centre moći u socijalizmu, no nemoć i beznađe s kojim se suočava čak i naizgled uspješan junak Timona (glumi ga sjajni Boris Buzančić) mogu se shvatiti i kao alegorije položaja bilo kojega individualca u društvu.

\section{Zaključak}

U govoru o hrvatskom autorskom i modernističkom filmu često se spominje utjecaj francuske kinematografije, pa je tako, prema Škrabalovu mišljenju Živa istina snimljena „u žanru filma istine” (Škrabalo 1998: 383) ${ }^{24}$. Riječ nije, dakako, o filmskom žanru, već o dokumentarističkom pokretu cinéma vérité, no N. Polimac (2010) s pravom umanjuje utjecaj toga pokreta, jer Radićev film uistinu ne počiva u tolikoj mjeri na intervjuima i svjesnoj interakciji čovjeka s kamerom - filmu istine je čak bliži Grlićev film Kud puklo da puklo.

No to što i danas duboko u 21. stoljeću ne možemo sa sigurnošću odrediti karakteristike Radićevog filma iz prve polovice 1970-ih, sasvim jasno govori o specifičnosti položaja umjetnika koje možemo nazvati kontestatorima dominantnih kinematografskih i društvenih vrijednosti. Ni dokumentarist ni tipičan autor igranog filma, smješten k tome između kazališta i filma, Radić je modernističkim rušenjem fikcije dokumentarnim stilom zbunio mnoge, premda su najveći filmski znalci prepoznali njegove vrhunce stvaralaštva (Timon, doduše, tek danas dobiva ugled koji zaslužuje). S druge strane, nije bilo ni govora o tome da bi Radić nastradao kao što se to dogodilo Lazaru Stojanoviću: čak i kada bi potpuno opravdana bila spomenuta Škrabalova implikacija da je Radićeva filmska karijera 1970-ih bila stopirana iz političkih razloga, Radić je svejedno djelovao u umjetničkom svijetu. Na Akademiji na kojoj se zaposlio i bio dekanom jedno je vrijeme (u doba socijalizma!) radila čak i njegova supruga, slabije poznata glumica Maja Freundlich koja je kasnije, 1990-ih, postala utjecajna HDZ-ova novinarka, veoma bliska predsjedniku Franji Tuđmanu.

${ }^{24}$ Jurica Pavičić (2011) za Kotlovinu kaže da bi se lakše uklopila u ladanjsku tradiciju francuskog filma nego u hrvatsku filmsku tradiciju. 
Dakle, premda nije bio disident kakvim su ga mogli smatrati 1990-ih, Radića možemo nazvati kontestatorom, koji početkom 1970-ih, nakon političkog obračuna s najpesimističnijim filmskim strujanjima, život u Jugoslaviji i dalje prikazuje crnim kao što su to činili prvaci srpskog crnog talasa (Živojin Pavlović, Dušan Makavejev) te njihovi srodnici u drugim jugoslavenskim republikama (Krsto Papić u Hrvatskoj, Bato Čengić u Bosni i Hercegovini). U tom smislu Radićev nacionalistički obrat 1990-ih nije sasvim neutemeljen jer su nove elite nakon pada socijalizma često gradile političke i institucijske mreže od disidenata i kontestatora. Budući da je dobar dio svoje karijere u socijalizmu Radić proveo i na nekim prestižnim pozicijama (uključujući i onu fakultetskog dekana), moglo bi se reći i da je istodobno riječ o čovjeku koji je pripadao socijalističkim društvenim elitama, pa se njegov tvrdi nacionalizam 1990-ih može čitati u sasvim drugom, kompenzacijskom ključu. Nove elite nakon pada socijalizma rado su uzimale i takve kadrove iz prethodnog režima.

Izmičući jednostavnim političkim i kulturološkim definicijama, Radić, dakako, ostaje jedan od najboljih i najvažnijih autora u povijesti hrvatskog filma, a to što ga ne možemo potpuno definirati zapravo ga čini itekako sličnim mnogim umjetnicima socijalističkog razdoblja europske povijesti, koji su činili kompromise i provocirali vlasti, u raznim fazama svoga života čineći različite izbore, smješteni negdje u šrrokom rasponu između režimskih umjetnika i neprijatelja države. To, doduše, može biti frustrirajuće za povjesničara koji bi htio jednostavno razvrstati autore i pojave, no povjesničari (filma ili bilo čega drugog) moraju biti spremni na kompleksne fenomene.

\section{Literatura}

Gilić N., 2011, Uvod u povijest hrvatskog igranog filma, Zagreb.

Heidl J., 2011a, Tomislav Radić - istina o Živoj istini, „Zapis” br. 72, <http://hfs.hr/ nakladnistvo_zapis_detail.aspx?sif_clanci=33937\#.Uc3zMEpX2H1>, 20.06.2013.

Heidl J., 2011b, Pričalo se da Tito nije htio gledati Živu istinu, „Hrvatska revija” br. 2-3, str. 134-139.

Kragić B., Gilić N. (ur.), 2003, Filmski leksikon, Zagreb, <http://enciklopedija.lzmk. $\mathrm{hr} />, 28.05 .2013$.

Oremović A., 2013, Slobodan Šijan. Živimo u vremenu nove ruralnosti i zato su festivali poput INmusica jako važni, „Večernji list” 23. lipnja, str. 38-39. 
Pavičić J., 2011, Kotlovina Tomislava Radića: film o hrvatskim malograđanima kao prijetvornoj i svadljivoj gomili, ,Jutarnji list” 16. rujna, <http://www.jutarnji.hr/tomislav-radic-kotovina-prica-o-hrvatskim-malogradanima-kao-prijetvornoj-i-svadljivoj-gomili/974613/>, 01.05.2013.

Polimac N., 2010, Film koji je probudio hrvatsku kinematografiju, „Zapis” br. 68, $<$ http://www.hfs.hr/nakladnistvo_zapis_detail.aspx?sif_clanci=32698\#.UY_xF0pK-bEo>, 24.04.2013.

Radić D., 2005, Prva hrvatska Dogma 95, „Nacional” 17. listopada br. 518, <http:// www.nacional.hr/clanak/21041/prva-hrvatska-dogma-95>, 20.04.2013.

Škrabalo I., 1998, 101 godina filma u Hrvatskoj 1896-1997, Zagreb.

Škrabalo I., 2008, Hrvatska filmska povijest ukratko, Zagreb.

Tretinjak I., 2012, Filmski modernizam i multimedijalnost Timona Tomislava Radića, „Hrvatski filmski ljetopis” br. 70, str. 39-59.

\section{Filmografija}

Anđele moj dragi, 1996, r. T. Radić, d.f. T. Pinter, Hrvatska.

Bure baruta, 1998, r. G. Paskaljević, d.f. M. Spasić, SR Jugoslavija (Srbija), Republika Makedonija, Francuska, Grčka, Turska.

Ciguli Miguli, 1952, r. B. Marjanović, d.f. N. Tanhofer, Jugoslavija.

Čovjek od željeza (Człowiek z żelaza), 1981, r. A. Wajda, d.f. E. Kłosiński, Poljska.

Godišnja doba, 1979, r. P. Krelja, d.f. I. Rajković, Jugoslavija.

Holding, 2001, r. T. Radić, d.f. V. Vrdoljak, Hrvatska.

Kotlovina, 2011, r. T. Radić, d.f. V. Šamanović, Hrvatska.

Kud puklo da puklo, 1974, r. R. Grlić, d.f. Ž. Zalar, Jugoslavija.

Luka, 1992, r. T. Radić, d.f. T. Pinter, Hrvatska.

Ljilja 4ever, 2002, r. L. Moodyson, d.f. U. Brantås, Danska, Švedska.

Pariz nam pripada (Paris nous appartient), 1961, r. J. Rivette, d.f. Ch.L. Bitsch, Francuska.

Plastični Isus, 1971, r. L. Stojanović, d.f. B. Perak, Jugoslavija.

Ritam zločina, 1981, r. Z. Tadić, d.f. G. Trbuljak, Jugoslavija.

Što je Iva snimila 21. listopada 2003., 2005, r. T. Radić, d.f. V. Šamanović, Hrvatska.

Timon, 1973, r. T. Radić, d.f. T. Pinter, Jugoslavija.

Tri priče o nespavanju, 2008, r. T. Radić, d.f. V. Šamanović, Hrvatska.

Živa istina, 1972, r. T. Radić, d.f. D. Novak, Jugoslavija. 
